\title{
Production of an $18 \%$ protein liquid micellar casein concentrate with a long refrigerated shelf life ${ }^{1}$
}

\author{
Irma Amelia and David M. Barbano ${ }^{2}$ \\ Northeast Dairy Foods Research Center, Department of Food Science, Cornell University, Ithaca, NY 14853
}

\begin{abstract}
Our objective was to develop a process to produce a high-concentration liquid micellar casein concentrate (18\% protein, MCC18) with a long refrigerated shelf life. The MCC18 is a novel milk protein ingredient produced by fractionating skim milk using microfiltration (MF). To achieve a long refrigerated shelf life, the processing of MCC18 was designed to maximize the removal of low-molecular weight compounds [e.g., lactose and nonprotein nitrogen (NPN)] that can be easily metabolized by microbes, while minimizing the microbial count in the final product. The production of MCC18 was done over a period of $5 \mathrm{~d}$. The experiment was replicated 3 times in different weeks with a different batch of raw milk. Raw whole milk was pasteurized and separated to produce skim milk. Skim milk was ultrafiltered (UF) to remove more than half of the lactose and NPN. The UF milk retentate was diluted with water and then MF in 3 stages to remove approximately $95 \%$ of the serum protein and further remove lactose and NPN. The retentate from the last stage of MF was UF to concentrate the protein to $18 \%$ and batch pasteurized. The MCC18 was collected immediately after processing in sterile plastic vials and stored at $4^{\circ} \mathrm{C}$. The average MCC18 contained $21.78 \%$ total solids, $18.27 \%$ true protein, $0.31 \%$ NPN, and $0.13 \%$ lactose. The MCC18 at the day of processing contained a mean aerobic bacterial count of $2.1 \mathrm{log}$ $\mathrm{cfu} / \mathrm{mL}$ and mean aerobic spore count of $2.3 \mathrm{log} \mathrm{cfu} /$ $\mathrm{mL}$. The MCC18 formed a solid gel at temperatures $<22^{\circ} \mathrm{C}$, but the $\mathrm{MCC} 18$ reverted back to a liquid when warmed from $4^{\circ} \mathrm{C}$ temperature to $>22^{\circ} \mathrm{C}$. This provides a unique opportunity in ingredient handling and packaging and eliminates the challenges encountered in reconstitution of dried milk protein ingredients. The MCC18 produced in this study maintained a bacteria
\end{abstract}

\footnotetext{
Received August 5, 2012.

Accepted January 16, 2013.

${ }^{1}$ Use of names, names of ingredients, and identification of specific models of equipment is for scientific clarity and does not constitute any endorsement of product by authors, Cornell University, or the Northeast Dairy Foods Research Center.

${ }^{2}$ Corresponding author: dmb37@cornell.edu
}

count $<20,000 \mathrm{cfu} / \mathrm{mL}$ for $16 \mathrm{wk}$ when stored at a refrigeration temperature of $4^{\circ} \mathrm{C}$. Further study is needed to determine if changes occur in the organoleptic and functional properties of MCC18. We envision that the conversion of skim milk to MCC and its coproducts (serum protein concentrate and lactose concentrate) could be used as an alternative to the production of nonfat dry milk to balance milk production seasonality, specifically the components of skim milk portion.

Key words: micellar casein, microfiltration, shelf life

\section{INTRODUCTION}

Milk production varies throughout the year. During the spring, milk production reaches its peak, whereas the lowest milk production occurs during the fall. This trend has been very consistent from year to year. Milk production is not always in phase with variations in consumption, and because of this the dairy industry faces seasonal supply and demand imbalances each year (Weldon et al., 2003). The current strategy to minimize inevitable loss due to milk surplus is to convert excess milk to storable products, such as NDM, cheese, and butter. In the production of NDM, excess skim milk often needs to be transported long distances to a drying facility. The high cost of transportation, evaporation, and drying to balance supply and demand reduces the profitability of the dairy industry. During milk deficit months, extra skim milk solids are needed for many products. A technology to store the high-value components in skim milk and to use them in the fall when milk production is low could be a lower cost milkbalancing strategy. Therefore, the goal of our study was to develop an alternative for balancing the milk production seasonality, specifically the skim milk portion, by using membrane technology. Skim milk consists of major components such as micellar casein, serum proteins, and lactose. Refining skim milk into well-defined fractions could lead to a more profitable use of milk components. The individual milk fractions can be used as ingredients that fulfill specific needs that cannot be delivered by milk itself to enhance nutritional values or to improve textural properties in food applications 
(Huffman and Harper, 1999). The isolated lactose from the milk filtration by-product can produce higher purity and yield compared with the one obtained from cheesemaking whey, because the lactose fractionated directly from skim milk does not contain cheesemaking residuals (rennet, culture, color, and lactic acid; Nelson and Barbano, 2005) and has value as an ingredient in food and pharmaceutical applications (Durham, 2009).

With the advancement of membrane filtration technology, the milk fractionation process has become more technically and economically feasible (Papadatos et al., 2003; Brans et al., 2004). A microfiltration (MF) unit can be installed in a fluid milk processing plant or cheese plant to separate excess skim milk and produce liquid micellar casein concentrate (MCC), liquid serum protein concentrate (SPC), and liquid lactose concentrate. Liquid MCC is a novel dairy ingredient that is characterized by high protein (mainly casein micelles) and low NPN and lactose contents. The more widely used methods to isolate caseins are isoelectric precipitation and proteolytic coagulation (Mulvihill and Ennis, 2003). Casein isolated by filtration is unique because the protein is in its micellar form and is not contaminated with any additives (e.g., acids, alkalis, and enzymes), which can affect the flavor profile of casein.

The feasibility of producing MCC by filtration processes has been demonstrated previously (Saboya and Maubois, 2000; Nelson and Barbano, 2005; Beckman et al., 2010; Hurt et al., 2010). Production and use of liquid MCC and SPC membrane concentrates would eliminate the costs associated with drying and would enhance the economic competitiveness of this approach. However, to capture this economic advantage, shelf-life stability of liquid protein concentrates becomes an important factor. Shelf-life stability of a product is defined as the time during which the product remains safe and exhibits no organoleptic defects (Muir, 1996). In general, the shelf life of a dairy product is limited by the growth of spoilage bacteria (Muir, 1996). Spoilage bacteria produce enzymes that can degrade milk constituents and cause unacceptable quality. A liquid MCC with a long refrigerated shelf life could be distributed long distances (with much less volume than original milk), also to be stored for future use when milk production is low and when additional casein is needed for cheese or cultured product production. To date, no report exists regarding the shelf-life stability of liquid MCC. Our objective was to develop a process to produce a highconcentration liquid micellar casein concentrate $(18 \%$ protein, MCC18) with a long refrigerated shelf life. For the purpose of this study, the end of shelf life was defined as total bacterial counts $>20,000 \mathrm{cfu} / \mathrm{mL}(>4.3$ $\log \mathrm{cfu} / \mathrm{mL})$.

\section{MATERIALS AND METHODS}

\section{Experimental Design and Statistical Analysis}

The production of MCC18 was done over a period of $5 \mathrm{~d}$ in the Cornell Pilot Plant (Ithaca, NY). The experiment was replicated 3 times, starting with a different batch of raw whole milk each time. All raw whole milk was received from the Cornell University dairy farm. Throughout the processing, the exposure of the product to open air was minimized by covering any open vats, tanks, and milk cans that were being used. This was done to avoid airborne contamination, especially from spores that were ubiquitous in the pilot plant environment. To have a long refrigerated shelf life, the processing of MCC18 was designed to maximize the removal of low-molecular weight compounds (e.g., lactose and NPN), which can be easily metabolized by microbes and used as nutrient sources. The manufacturing process involved UF and multiple stages of MF in which low-molecular-weight compounds were removed with the permeate. Another strategy to prolong refrigerated shelf life was to minimize the microbial count in the final product, which was achieved through gravity separation (Caplan et al., 2013) and pasteurization. The final product of pasteurized MCC18 at wk 0 was analyzed for total aerobic bacteria and spores. Over the course of $16 \mathrm{wk}$, the total aerobic bacteria count was determined weekly to assess the shelf-life stability of MCC18 stored at $4^{\circ} \mathrm{C}$. It is important to note that due to the capacity of the processing equipment and limited staffing, the complete manufacturing process required $5 \mathrm{~d}$. However, in a factory setting, it would be a continuous process that would run continuously in the same day. Thus, from a microbial contamination and microbial growth perspective, the processing conditions in our study probably resulted in a worst-case scenario in a process designed for this purpose.

To determine the chemical composition of pasteurized skim milk, MF stage 1 to 3 retentate, and pasteurized MCC 18 at wk 0, the data were analyzed by ANOVA using PROC GLM of SAS (version 8.02; SAS Institute Inc., Cary, NC), which was followed by running the least squares means if the F-test for the model was significant (i.e., $P<0.05$ ). Bacterial and spore data were log transformed and used as a response in a GLM model to determine if significant differences existed in log bacterial and spore counts in raw milk, gravityseparated cream, gravity-separated skim milk, pasteurized gravity-separated skim milk, pasteurized skim milk, UF milk retentate, MF stage 1 retentate, MF stage 3 retentate, and MCC18 before and after batch pasteurization. To determine if the effect of replicate and time (week of storage) were significant, the data 
for $\log$ bacterial count of MCC18 at wk 0 to 16 were analyzed by ANOVA. The model was dependent variable (log bacterial count MCC18) = time + replicate + time $\times$ replicate + error. Replicate was treated as a categorical variable. Time was treated as a continuous variable and was transformed by mean centering the weeks of storage to minimize distortion of the ANOVA model by multicollinearity (Glantz and Slinker, 2001). Time was transformed as follows: time $=$ week of storage $-[($ wk $16-$ wk 0$) / 2]$.

\section{Manufacturing of MCC18}

The processing overview of MCC18 production is shown in Figure 1. The processing on each day was described in detail as follows:

Days 1 and 2. On d 1, raw whole milk (approximately $1,170 \mathrm{~kg}$ ) was weighed into cone-bottom gravity-separation tanks and held at $4^{\circ} \mathrm{C}$. After $20 \mathrm{~h}$ at $4^{\circ} \mathrm{C}$, the bottom $90 \%$ of the milk in each tank was collected by weight. The gravity-separated cream was not used in the present study. The bottom $90 \%$ of the milk (gravity-separated skim milk, about $2.2 \%$ fat) was then pasteurized at $72^{\circ} \mathrm{C}$ for $16 \mathrm{~s}$ with a plate heat exchanger with 3 sections: regeneration, heating, and cooling (model 080-S; AGC Engineering Inc., Manassas, VA), and then separated at $49^{\circ} \mathrm{C}$ using a cream separator (model 619; DeLaval Co., Chicago, IL). The pasteurized skim milk was $\mathrm{UF}\left(50^{\circ} \mathrm{C}\right)$ using a polyethersulfone spiral-wound UF membrane with a nominal pore size of 10,000 Da (model 3838; GEA Niro Inc., Hudson, WI) in a batch recirculation mode $(2.2 \times$ concentration factor, or CF). The UF system was a 2-pump system with a feed pump and a recirculation pump to maintain crossflow velocity and minimize fouling. Prior to and after UF processing, the UF membrane system was cleaned using the procedures described previously by Evans et al. (2009). The purpose of this UF step was to remove a little more than half of the lactose and NPN from the skim milk before MF. The UF retentate inlet pressure was $276 \mathrm{kPa}$, and the retentate outlet pressure was 103 $\mathrm{kPa}$. The retentate and permeate composition (e.g., protein, lactose, and fat) was analyzed every $15 \mathrm{~min}$ for process control using an infrared spectrophotometer (LactoScope FTIR; Delta Instruments BV, Drachten, the Netherlands). At the end of the UF processing run, the retentate was diluted with cold reverse osmosis (RO) water $\left(4^{\circ} \mathrm{C}\right)$ to decrease the protein content to the level in the original skim milk, which was followed by storage overnight at $4^{\circ} \mathrm{C}$.

Day 3. The RO water-diluted UF retentate was heated to $50^{\circ} \mathrm{C}$ using a plate heat exchanger (model A3; DeLaval Inc., Kansas, MO) and then fed into an MF system (Tetra Alcross MFS-7; Tetra Pak Filtration

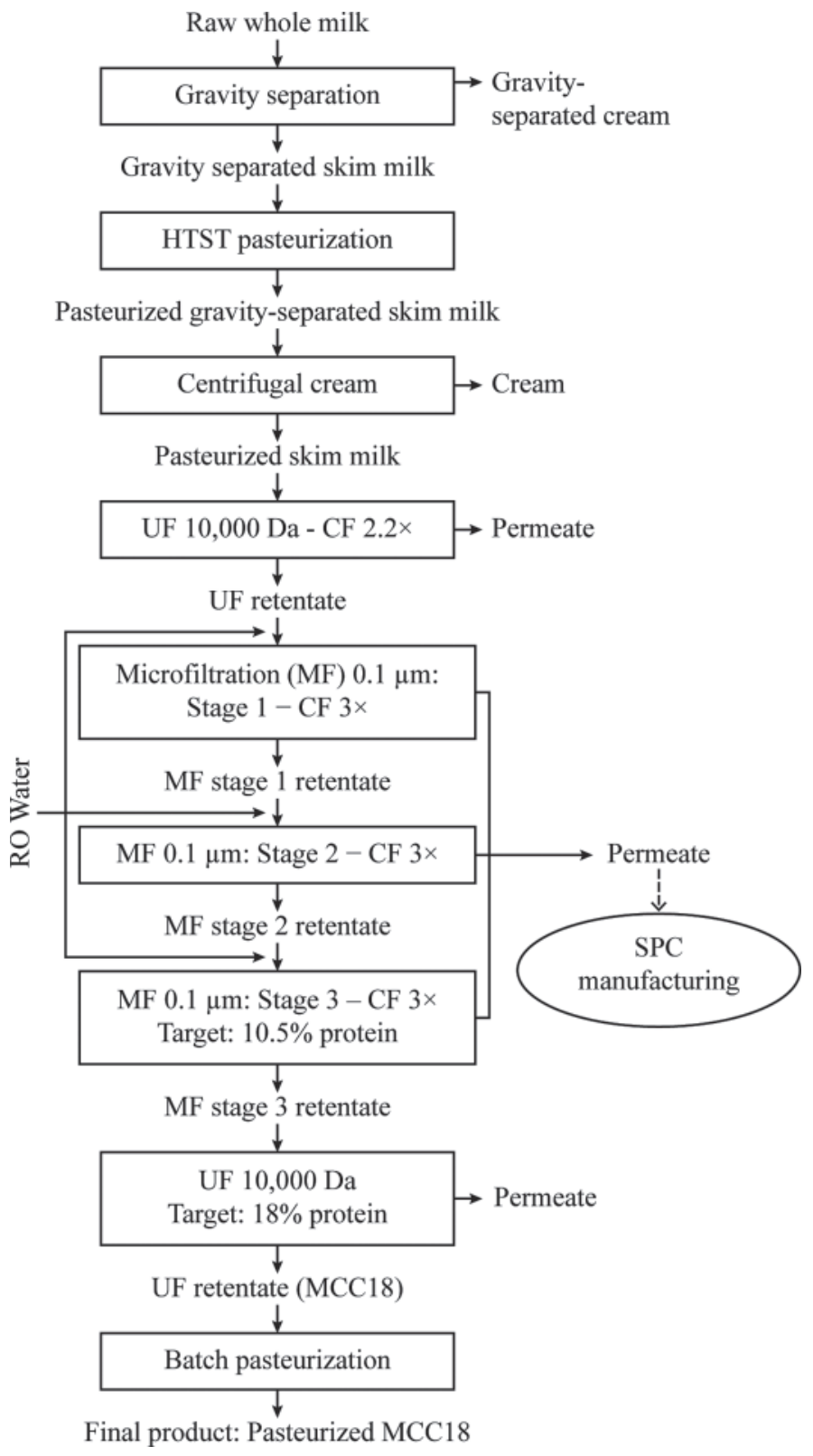

Figure 1. Schematic process diagram of liquid micellar casein concentrate with $18 \%$ protein (MCC18) with a long refrigerated shelf life. $\mathrm{CF}=$ concentration factor; $\mathrm{RO}=$ reverse osmosis; $\mathrm{SPC}=$ serum protein concentrate.

Systems, Pleasant Prairie, WI) with $0.1-\mu \mathrm{m}$ nominal pore diameter ceramic Membralox graded-permeability membrane (model EP1940GL0.1 $\mu$ AGP1020, alumina; Pall Corp., Cortland, NY) and $1.7-\mathrm{m}^{2}$ surface area. This MF process (MF stage 1) was a continuous bleed and feed. The $\mathrm{CF}$ was set to $3 \times$, with retentate and permeate removal rates of 60 and $120 \mathrm{~L} / \mathrm{h}$, respectively, which produced an MF permeate flux of $70 \mathrm{~L} / \mathrm{m}^{2} \mathrm{~h}$. The MF retentate was cooled and held at $4^{\circ} \mathrm{C}$ to be processed the next day. The detailed procedures for the 
cleaning of the ceramic graded-permeability membrane system before and after milk processing are provided by Zulewska et al. (2009).

Day 4. The MF retentate from the previous day was diluted with RO water to achieve a target true protein of $2.8 \%$, as measured by an infrared spectrophotometer. It was then heated to $50^{\circ} \mathrm{C}$ by an $\mathrm{AGC}$ plate heat exchanger (model 080-S; AGC Engineering, Manassas, VA) before being MF. This MF diafiltration process (MF stage 2) was a continuous bleed and feed with a $\mathrm{CF}$ of $3 \times$. The retentate and permeate removal rates were set to 70 and $140 \mathrm{~L} / \mathrm{h}$, respectively, resulting in an MF permeate flux of $82 \mathrm{~L} / \mathrm{m}^{2} \mathrm{~h}$. The stage- 2 MF retentate was mixed with $\left.50^{\circ} \mathrm{C} \mathrm{RO}\right)$ water $(2 \mathrm{~kg}$ of $\mathrm{RO}$ water per $1 \mathrm{~kg}$ of retentate) and used as the feed solution for MF stage 3. The retentate and permeate removal rates at MF stage 3 were maintained at 70 and $140 \mathrm{~L} / \mathrm{h}$, respectively, resulting in an MF permeate flux of $81 \mathrm{~L} / \mathrm{m}^{2} \mathrm{~h}$ and the final MF retentate was concentrated to $10.5 \%$ protein, as measured using an infrared spectrophotometer, in a batch operation process. The sampling of MF stage 3 retentate was taken from the feed tank into which the retentate was collected and mixed with the feed solution. The product was cooled to $4^{\circ} \mathrm{C}$ and stored, to be processed the next day.

Day 5. The MF retentate was heated to $50^{\circ} \mathrm{C}$ and then UF in a batch operation process. The purpose of this step was primarily to concentrate the protein to about $18 \%$, but it also removed some additional lactose and NPN. The retentate inlet pressure was $276 \mathrm{kPa}$, and the retentate outlet pressure was $103 \mathrm{kPa}$. The UF process was stopped when the protein content of the product in the feed tank was $18 \%$, as measured using an infrared spectrophotometer. The resulting MCC18 was batch pasteurized at $157^{\circ} \mathrm{F}$ for $30 \mathrm{~min}$ in a stainless steel jacketed steam kettle (Groen DN30; Groen Manufacturing Co., Chicago, IL) to kill vegetative bacterial cells. Liquid MCC18 after batch pasteurization was immediately collected into forty-eight $90-\mathrm{mL}$ plastic snaptop vials (model CPP03CL; Capitol Vial Inc., Auburn, $\mathrm{AL}$ ) and stored in a $4^{\circ} \mathrm{C}$ cooler. Thirty-two filled vials were designated for shelf-life study to determine bacterial growth over a 16-wk period, and the rest of the vials were used for chemical analyses.

\section{Chemical Analyses}

Samples of pasteurized skim milk, permeate, and retentate at each filtration stage were analyzed in duplicate for TS by drying in a forced-air oven at $100^{\circ} \mathrm{C}$ for 4 h (AOAC International, 2000; section 33.2.44, method 990.20), fat content by ether extraction (AOAC International, 2000; section 33.2.26, method 989.05), lactose by the enzymatic method (AOAC International, 2000; section 33.2.67, method 2006.06; Lynch et al., 2007) using Megazyme lactose kit no. K-LACGAR (Megazyme International Ireland Ltd., Bray, County Wicklow, Ireland). The total N (TN) and NPN were determined in duplicate by the Kjeldahl method (AOAC International, 2000; section 33.2.11, method 991.20; section 22.2.12, method 991.21, respectively). For MCC18, the analyses of TN and NPN were done in triplicate. True protein (TP) was calculated by subtracting NPN from TN. The nitrogen conversion factor used was 6.38. The high protein retentates were diluted with $\mathrm{RO}$ water to a protein level similar to milk for TN and NPN analyses.

\section{Microbiological Analyses}

Total aerobic bacteria and spores counts were determined for the incoming raw milk, gravity-separated cream, gravity-separated skim milk, pasteurized skim milk, UF milk retentate, MF stage 1 retentate, MF stage 3 retentate, and the final product of MCC 18 after batch pasteurization. The $\mathrm{RO}$ water used in the diafiltration steps was also analyzed for total aerobic bacteria and spores. All the samples were held at $4^{\circ} \mathrm{C}$ before analysis, which was done on the same day the sample was collected. For the total aerobic bacteria (method 6.040; Wehr and Frank, 2004), samples were collected in sterile $90-\mathrm{mL}$ plastic snap-top vials (model CPP03CL; Capitol Vial Inc.). For the total aerobic bacterial spore count (method 8.090; Wehr and Frank, 2004), the samples were collected into sterile $300-\mathrm{mL}$ plastic snap-top vials (model CPP10LK-CL; Capitol Vial Inc.) to hold approximately $200 \mathrm{~mL}$ of sample. Samples were incubated in a water bath until the temperature reached $80^{\circ} \mathrm{C}$ and then held for $12 \mathrm{~min}$ to germinate the spores. A pilot vial filled with the same sample material was used as a temperature control to avoid contaminating the actual sample when in contact with the thermometer probe. The sample was cooled in an ice bath until the temperature reached at least $35^{\circ} \mathrm{C}$ before being plated. The 3M Petrifilm aerobic count plates (3M, St. Paul, MN) were used for both aerobic bacteria and spores enumeration. For each sample, serial dilutions were made in a sterile phosphate buffer (Weber Scientific, Hamilton, NJ), and each dilution was plated in quadruplicate. All Petrifilm plates were incubated at $32 \pm 1{ }^{\circ} \mathrm{C}$ for $48 \pm 3 \mathrm{~h}$. Petrifilm plates containing 25 to 250 colonies were counted when determining total aerobic bacteria, and the reported count was rounded to 2 significant digits (method 6.020; Wehr and Frank, 2004). For sequential dilutions that both contained 25 to 250 colonies, the reported count was calculated using the following formula: $\mathrm{n}=$ $\Sigma \mathrm{C} /\left[\left(1 \times \mathrm{n}_{1}\right)+\left(0.1 \times \mathrm{n}_{2}\right)\right] \times \mathrm{d}$, where $\mathrm{n}=$ number of colonies $(\mathrm{cfu} / \mathrm{mL}), \Sigma \mathrm{C}=$ sum of all colonies on all 
plates counted, $\mathrm{n}_{1}=$ number of plates in lower dilution counted, $\mathrm{n}_{2}=$ number of plates in next higher dilution counted, and $\mathrm{d}=$ dilution from which the first counts were obtained (method 6.020; Wehr and Frank, 2004).

\section{Shelf-Life Study}

Two vials were selected randomly from the population of 32 vials for total aerobic bacteria count each week for a period of $16 \mathrm{wk}$ using the $3 \mathrm{M}$ Petrifilm aerobic count method. After sampling, the remainder of product in that vial was discarded. The MCC18 formed a firm gel at $4^{\circ} \mathrm{C}$; thus, the vial was tempered in a $45^{\circ} \mathrm{C}$ water bath for 20 min to liquefy the sample for ease of sampling and plating. For the purpose of this study, the end of shelf life was defined as total bacterial counts $>20,000 \mathrm{cfu} / \mathrm{mL}(>4.3 \log \mathrm{cfu} / \mathrm{mL})$. The cutoff of $20,000 \mathrm{cfu} / \mathrm{mL}$ has been used as the legal limit for the shelf life of pasteurized milk based on the Pasteurized Milk Ordinance (FDA, 2009).

\section{RESULTS AND DISCUSSION}

\section{Microbiological Analyses}

Microbiological quality of the raw milk was assessed by determining total aerobic bacterial and spore counts. The mean bacterial count of the raw milk from the 3 replicates was $3.8 \log \mathrm{cfu} / \mathrm{mL}$ (Table 1 ). The spore count in the raw milk was reported as $<1.4 \log$ cfu/ $\mathrm{mL}$ because it was below the optimal countable range (25 to 250 colonies/plate) for all 3 replicates (Table 2). When the raw milk was gravity separated, the fat rose to the top along with bacteria and spores. After $20 \mathrm{~h}$ at $4^{\circ} \mathrm{C}$, the mean bacterial count in the top $10 \%$ of the raw milk by weight (gravity-separated cream) was 5.0 $\log \mathrm{cfu} / \mathrm{mL}$, which was significantly higher $(P<0.05)$ than in the raw milk before gravity separation, whereas the mean spore count in the gravity-separated cream was $2.2 \log \mathrm{cfu} / \mathrm{mL}$ (Tables 1 and 2 , respectively). The gravity-separated skim milk was collected, and the bacteria in this portion was significantly reduced $(P<$ $0.05)$ to an average count of $2.8 \mathrm{log} \mathrm{cfu} / \mathrm{mL}$ (Table 1 ) compared with the bacteria in the raw milk. The mean spore count of the gravity-separated skim milk was $<1.4 \log \mathrm{cfu} / \mathrm{mL}$ for all 3 replicates. It is crucial to remove spores originating from raw milk because they are capable of germinating under refrigeration temperature and eventually limit the shelf life of the final product (Fromm and Boor, 2004; Barbano et al., 2006). It was shown in this study that the use of gravity separation in the raw milk removed spores and bacteria from the gravity-separated skim milk portion by concentrating them in the cream portion. This observation has been reported in previous studies, although the mechanism of this natural process is not understood (Dellagio et al., 1969; Caplan et al., 2013).

The HTST pasteurization of the gravity-separated skim milk reduced bacterial count to $<1.4 \log \mathrm{cfu} / \mathrm{mL}$ (Table 1). The spore count of the pasteurized gravityseparated skim milk was $<1.4 \log \mathrm{cfu} / \mathrm{mL}$, except in replicate 3 with $1.7 \log \mathrm{cfu} / \mathrm{mL}$ (Table 2). The next steps in processing, which included centrifugal separation, UF, and MF, were expected to increase microbial count due to environmental contamination. Because UF and MF membranes used in this study had smaller pore size than the size of microbes $(0.4$ to $2.0 \mu \mathrm{m})$, microbes that survived pasteurization and any microbial contamination introduced during processing and handling were retained by the membrane and con-

Table 1. Total aerobic bacterial counts in raw whole milk, gravity-separated cream, gravity-separated skim milk, pasteurized gravity-separated skim milk, pasteurized skim milk, UF milk retentate, microfiltration (MF) stage 1 retentate, MF stage 3 retentate, and micellar casein concentrate with 18\% protein (MCC18) before and after batch pasteurization for replicates 1,2 , and 3

\begin{tabular}{|c|c|c|c|c|}
\hline \multirow[b]{2}{*}{ Material } & \multicolumn{4}{|c|}{ Total aerobic bacteria, log $\mathrm{cfu} / \mathrm{mL}$} \\
\hline & Replicate 1 & Replicate 2 & Replicate 3 & Mean $^{1}$ \\
\hline Raw whole milk & 3.4 & 4.1 & 4.0 & $3.8^{\mathrm{b}}$ \\
\hline Gravity-separated cream & 4.9 & 5.1 & 5.0 & $5.0^{\mathrm{a}}$ \\
\hline Gravity-separated skim milk & 2.5 & 3.0 & 3.0 & $2.8^{\mathrm{e}}$ \\
\hline Pasteurized gravity-separated skim milk & $<1.4^{2}$ & $<1.4$ & $<1.4$ & - \\
\hline Pasteurized skim milk & $<1.4$ & $<1.4$ & 1.5 & - \\
\hline UF milk retentate & 1.7 & 1.5 & 2.1 & $1.8^{\mathrm{h}}$ \\
\hline MF stage 1 retentate & 1.7 & 1.7 & 3.2 & $2.2^{\mathrm{f}}$ \\
\hline MF stage 3 retentate & 2.4 & 3.9 & 3.6 & $3.3^{\mathrm{d}}$ \\
\hline MCC18 before batch pasteurization & 2.9 & 3.4 & 3.8 & $3.4^{\mathrm{c}}$ \\
\hline Final product: pasteurized MCC18 & 2.0 & 1.9 & 2.3 & $2.1^{\mathrm{g}}$ \\
\hline
\end{tabular}


Table 2. Total aerobic spore counts in raw whole milk, gravity-separated cream, gravity-separated skim milk, pasteurized gravity-separated skim milk, pasteurized skim milk, UF milk retentate, microfiltration (MF) stage 1 retentate, MF stage 3 retentate, micellar casein concentrate with $18 \%$ protein (MCC18) before batch pasteurization, and pasteurized MCC 18 for replicates 1,2 , and 3

\begin{tabular}{lcccc}
\hline & \multicolumn{3}{c}{ Total aerobic spores, log cfu/mL } \\
\cline { 2 - 5 } Material & Replicate 1 & Replicate 2 & Replicate 3 & Mean $^{1}$ \\
\hline Raw whole milk & $<1.4^{2}$ & $<1.4$ & $<1.4$ & - \\
Gravity-separated cream & 2.0 & 2.1 & 2.7 & $2.2^{\mathrm{c}}$ \\
Gravity-separated skim milk & $<1.4$ & $<1.4$ & $<1.4$ & - \\
Pasteurized gravity-separated skim milk & $<1.4$ & $<1.4$ & 1.7 & - \\
Pasteurized skim milk & $<1.4$ & $<1.4$ & 1.9 & - \\
UF milk retentate & $<1.4$ & $<1.4$ & 2.1 & - \\
MF stage 1 retentate & $<1.4$ & 1.6 & 2.2 & $2.2^{\mathrm{c}}$ \\
MF stage 3 retentate & 2.1 & 1.9 & 2.7 & $2.4^{\mathrm{a}}$ \\
MCC18 before batch pasteurization & 2.5 & 1.9 & 2.9 & $2.3^{\mathrm{b}}$ \\
Final product: pasteurized MCC18 & 2.5 & 1.8 & 2.6 &
\end{tabular}

${ }^{\mathrm{a}-\mathrm{c}}$ Means within the same column not sharing a common superscript are different $(P<0.05)$.

${ }^{1}$ Standard error $=0.017$.

${ }^{2}$ The result was below the optimal countable range of 25 to $250 \mathrm{cfu} / \mathrm{mL}$ before being $\log$ transformed.

centrated in the same manner as the casein micelles (Saboya and Maubois, 2000; Brans et al., 2004). The microbial load of RO water used in the diafiltration steps was analyzed and found to have $<1.4 \log \mathrm{cfu} /$ $\mathrm{mL}$ for both total bacterial and spore counts, except in replicate 1 , which had a total bacteria count of $1.72 \mathrm{log}$ $\mathrm{cfu} / \mathrm{mL}$ and total spore count of $1.73 \log \mathrm{cfu} / \mathrm{mL}$. As expected, the mean bacterial count showed a significant increase during successive UF and MF process. The mean bacterial count of UF milk retentate, MF stage 1 retentate, MF stage 3 retentate, and MCC 18 before being batch pasteurized were 1.8, 2.2, 3.3, and $3.4 \log$ $\mathrm{cfu} / \mathrm{mL}$, respectively (Table 1 ). At the end of MF stage 3 , the mean spore count in the retentate was $2.2 \mathrm{log}$ $\mathrm{cfu} / \mathrm{mL}$ and concentrated to $2.4 \mathrm{log} \mathrm{cfu} / \mathrm{mL}$ in MCC18 before being batch pasteurized (Table 2). The batch pasteurization of MCC18 as the last processing step was conducted to reduce vegetative bacterial cells that were introduced and concentrated during processing and handling. The final MCC18 at wk 0 had mean bacteria count of $2.1 \log \mathrm{cfu} / \mathrm{mL}$ and mean spore count of $2.3 \log \mathrm{cfu} / \mathrm{mL}$.

\section{Chemical Analyses}

Pasteurization of the gravity-separated skim milk was carried out at $72^{\circ} \mathrm{C}$ for $16 \mathrm{~s}$ to produce minimal heat denaturation of SP and binding of SP to casein, which can negatively affect the removal of serum protein (Hurt and Barbano, 2010). The MF stage 3 was initially a bleed and feed process with $3 \times \mathrm{CF}$, but at the end of the run, the retentate was concentrated in a batch operation process, which accounted for an increase in TS, TN, and TP from the MF stage 2 retentate to MF stage 3 retentate (Table 3 ). The MF stage 3 retentate was further concentrated using UF to produce higher TS, TN, and TP in the final MCC18 (Table 3). Protein expressed as $\mathrm{TN} \times 6.38$ is provided on a wet and a dry weight basis in Table 3 to show how protein as a percentage of solids increased throughout the process. The principal NPN compounds in milk include urea, creatine, creatinine, uric acid, orotic acid, hippuric acid, peptide, ammonia, and $\alpha$-amino acid (WolfschoonPombo and Klostermeyer, 1981), all of which are small enough in size to pass freely through UF and MF membranes (Saboya and Maubois, 2000). The nitrogen from these low-molecular weight compounds is more readily utilized by microbes (Ray, 2003) as a nutrient source compared with the nitrogen from more complex compounds (e.g., intact proteins). Therefore, the removal of NPN during the filtration process was expected to improve the shelf stability of MCC18. In theory, NPN content in the retentate would be reduced throughout the filtration process. The NPN in MF stage 2 retentate and MF stage 3 retentate was lower than in skim milk $(P<0.05$; Table 3$)$. The last UF processing step increased the NPN value from $0.12 \%$ in the MF stage 3 retentate to $0.27 \%$ in the final pasteurized MCC18 (Table 3). The increase in NPN from the MF stage 3 retentate to pasteurized MCC18 gave the impression that the NPN was retained by the UF membrane, although it was plausible that the NPN measured in this sample was not the typical low-molecular weight nitrogen compounds associated in milk. As an example, phospholipids in milk (e.g., phosphatidylcholine and phosphatidylethanolamine) contain nitrogen (Fox and McSweeney, 1998) that could be soluble in $12 \%$ TCA and, hence, would be counted as NPN. Phospholipids as part of milk fat globule membranes present in the skim milk were concentrated throughout the UF and 
Table 3. Mean $(\mathrm{n}=3)$ composition of pasteurized skim milk, microfiltration (MF) stage 1 retentate, MF stage 2 retentate, MF stage 3 retentate, and pasteurized micellar casein concentrate with $18 \%$ protein (MCC18)

\begin{tabular}{|c|c|c|c|c|c|c|c|}
\hline Sample & $\mathrm{TS}$ & $\mathrm{TN}^{1}$ & $\begin{array}{c}\text { TN } \\
(\mathrm{dwb})^{2}\end{array}$ & $\underset{\%}{\mathrm{NPN},{ }^{3}}$ & $\mathrm{TP}_{\%}^{4}$ & $\begin{array}{c}\mathrm{NPN} \% \mathrm{TP} \\
\%\end{array}$ & $\begin{array}{c}\text { Lactose, } \\
\%\end{array}$ \\
\hline $\begin{array}{l}\text { Pasteurized skim milk } \\
\text { MF stage } 1 \text { retentate } \\
\text { MF stage } 2 \text { retentate } \\
\text { MF stage } 3 \text { retentate } \\
\text { Pasteurized MCC18 } \\
\text { SE }\end{array}$ & $\begin{array}{r}9.09^{\mathrm{d}} \\
11.01^{\mathrm{c}} \\
9.16^{\mathrm{d}} \\
13.30^{\mathrm{b}} \\
21.78^{\mathrm{a}} \\
0.251\end{array}$ & $\begin{array}{r}3.25^{\mathrm{d}} \\
7.75^{\mathrm{c}} \\
7.40^{\mathrm{c}} \\
11.21^{\mathrm{b}} \\
18.58^{\mathrm{a}} \\
0.172\end{array}$ & $\begin{array}{c}35.78^{\mathrm{d}} \\
70.40^{\mathrm{c}} \\
80.70^{\mathrm{b}} \\
84.24^{\mathrm{ab}} \\
85.36^{\mathrm{a}} \\
0.880\end{array}$ & $\begin{array}{l}0.191^{\mathrm{b}} \\
0.122^{\mathrm{bc}} \\
0.074^{\mathrm{c}} \\
0.117^{\mathrm{c}} \\
0.271^{\mathrm{a}} \\
0.015\end{array}$ & $\begin{array}{r}3.06^{\mathrm{d}} \\
7.63^{\mathrm{c}} \\
7.32^{\mathrm{c}} \\
11.09^{\mathrm{b}} \\
18.27^{\mathrm{a}} \\
0.147\end{array}$ & $\begin{array}{l}6.22^{\mathrm{a}} \\
1.60^{\mathrm{b}} \\
1.01^{\mathrm{b}} \\
1.05^{\mathrm{b}} \\
1.47^{\mathrm{b}} \\
0.128\end{array}$ & $\begin{array}{l}4.74^{\mathrm{a}} \\
1.93^{\mathrm{b}} \\
0.64^{\mathrm{c}} \\
0.19^{\mathrm{d}} \\
0.13^{\mathrm{e}} \\
0.0009\end{array}$ \\
\hline
\end{tabular}

MF process, and the phospholipids may have become a substantial fraction of the NPN. When NPN was measured as a percent of total protein (NPN\% TP), a significant reduction was seen from the pasteurized skim milk $(6.22 \%)$ to MF stage 1 retentate (1.6\%). Further reduction in NPN\%TP in the remainder of the process was not detected. The NPN\%TP of the MCC18 was $1.47 \%$, significantly lower than of the skim milk. The mean lactose content was reduced significantly $(P$ $<0.05$ ), from $4.74 \%$ in the pasteurized skim milk to $0.13 \%$ in the final MCC18 (Table 3). Lactose serves as a carbon source and provides nutrients for microbial growth. Lowering the amount of lactose could act as a hurdle for microbial growth; thus, it can be beneficial in prolonging the shelf-life of MCC18.

\section{Shelf-Life Study}

The aerobic bacterial count of the pasteurized MCC18 immediately after manufacturing (at wk 0) was determined to be $2.0,1.9$, and $2.3 \log \mathrm{cfu} / \mathrm{mL}$ for replicates 1,2 , and 3 , respectively (Table 1 ). The mean aerobic bacterial counts of the MCC18 from 2 vials randomly sampled at each week were plotted as a function of weeks of storage for replicates 1,2, and 3 (Figure 2 ). In replicate 2 for 1,5 , and 6 wk of storage, the aerobic bacterial counts of MCC18 between the 2 vials were greater than 2-log difference. The vial with higher aerobic bacterial count was suspected to have postprocessing contamination (e.g., accidentally touching the sample during the open-air hand filling). Therefore, the high count might not have represented the aerobic bacterial count of the actual product. These possible outliers were removed when running the ANOVA test to determine the effect of time (week of storage), replicate, and time $\times$ replicate. No change in the aerobic bacterial count over 16 wk $(P>0.05)$ was detected; however, the effect of replicate on the aerobic bacterial count was significant $(P<0.05)$. The interaction effect between time and replicate was not significant $(P>0.05)$ and was removed from the model. With the effect of time being nonsignificant $(P>0.05)$, it was concluded that the bacteria in MCC18 were still in the lag phase and not actively proliferating during $16 \mathrm{wk}$ of storage in $4^{\circ} \mathrm{C}$. The spore counts of the pasteurized MCC18 at wk 0 were determined to be 2.5, 1.8, and $2.6 \log \mathrm{cfu} / \mathrm{mL}$ for replicates 1,2 , and 3 , respectively. No indication of spore germination existed over $16 \mathrm{wk}$ of storage at $4^{\circ} \mathrm{C}$. Given the end of shelf life defined as bacterial count over $>4.3 \log \mathrm{cfu} / \mathrm{mL}, \mathrm{MCC} 18 \mathrm{manu}-$ factured in this study was shown to have a microbial shelf life of at least $16 \mathrm{wk}$ when stored at a refrigeration temperature of $4^{\circ} \mathrm{C}$.

\section{Implications for the Dairy Industry}

The processing method proposed in this study includes, among others, gravity separation and membrane filtration. Gravity separation of milk is an efficient technique to remove spores and thermoduric bacteria (Caplan et al., 2013). Moreover, gravity separation is a simple technology that can be implemented with minimal additional capital and operating cost. The use of membrane filtration technology has increased in the dairy industry, especially with the advanced development of membrane designs and system configurations that can minimize fouling and improve flux and selectivity while maintaining chemical and heat stability of the membrane during prolonged use (Saboya and Maubois, 2000). The economic feasibility of using $2 \times$ MF at the beginning of cheesemaking was positive and the components of processing costs were reported by Papadatos et al. (2003). To build on the data from Papadatos et al. (2003) for the process described in 


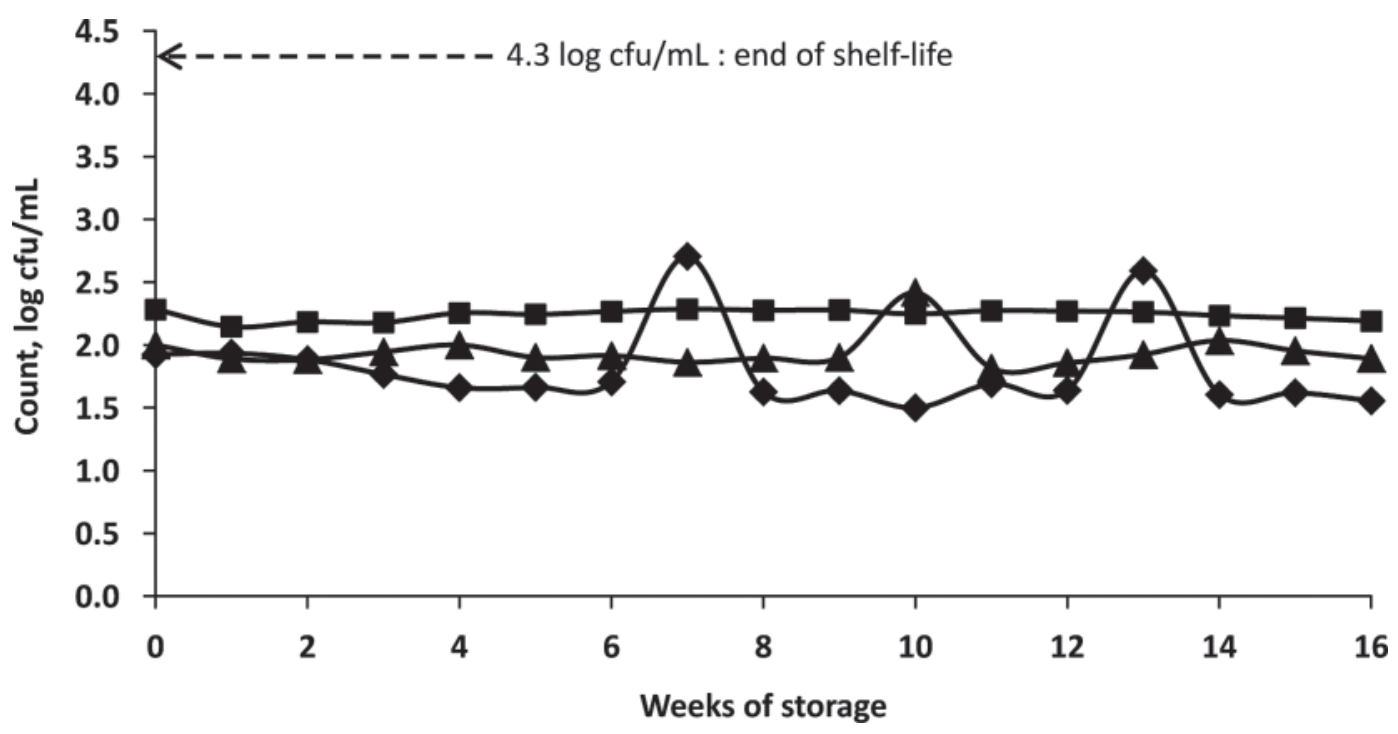

Figure 2. Log total bacteria count of micellar casein concentrate with $18 \%$ protein (MCC18) determined weekly over a 16 -wk period for replicate $1(\boldsymbol{\Delta})$, replicate $2(\bullet)$, and replicate $3(\boldsymbol{\square})$.

the current work, the cost of additional UF would be needed to produce the high-protein concentrates. More work is needed to specifically estimate the processing costs for production of MCC18.

The MCC18 is a pourable liquid at room temperature $\left(22^{\circ} \mathrm{C}\right)$ or higher, and becomes gel at refrigeration temperature $\left(4^{\circ} \mathrm{C}\right)$ or lower (Figure 3$)$. With this property, it is important that MCC18 needs to maintain high enough temperature during processing to prevent clogging in the processing lines. A hot fill process would be ideal for MCC18. The solid consistency of MCC18 during refrigeration storage provides ease of handling and transporting in wide variety of bulk packaging and handling systems.

The permeate from MCC production contains valuable components that can be processed to produce SPC and lactose concentrate. In determining the economic feasibility of skim milk fractionation, the processing of all individual milk fractions (MCC, SPC, and lactose concentrate) needs to be evaluated. The resulting products of this process are not standard dairy commodity products; instead, they are value-added ingredients that could have higher economic value in the market due to their distinct functional properties.

The MCC18 could be used as an ingredient in cheesemaking for non-standard of identity cheeses in the United States. The MCC18 could also be used as functional protein ingredient to achieve fat reduction in low-fat versions of cheeses with a standard of identity. At the present time in the United States, it would require a change in the standard of identity for a full-fat cheese such as Cheddar or Mozzarella to allow the use of MCC18 as an ingredient. Casein is the primary pro- tein that is retained in the cheese curd, whereas other proteins are lost in the whey. The use of MCC could be beneficial for cheesemaking because it would increase the amount of cheese produced per day, given the same volume of the starting material in a vat. Consequently, the utilization of the plant capacity will be maximized. Pierre et al. (1992) reported a reduction in coagulation time and an increase in cheese curd firmness when using reconstituted MCC powder as the starting material instead of raw milk. Papadatos et al. (2003) demonstrated that the use of MF milk (rich in casein) in Cheddar cheese making resulted in greater net revenue compared with the one using NDM and condensed milk for fortification. The minimal serum protein present in MCC reduced the detrimental effect of heating on ren-
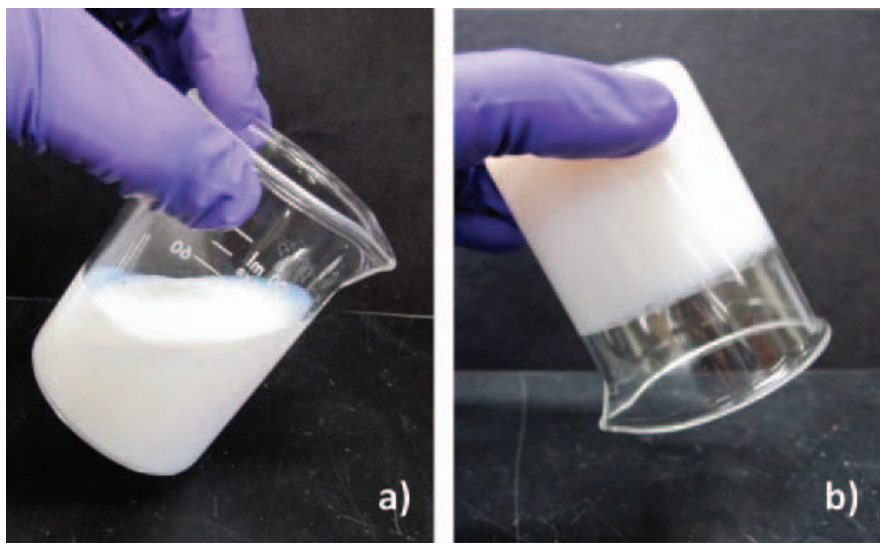

Figure 3. Micellar casein concentrate with $18 \%$ protein exists in a liquid form at $22^{\circ} \mathrm{C}$ (a) and as a firm gel at $4^{\circ} \mathrm{C}$ (b). Color version available in the online PDF. 
net coagulability (Saboya and Maubois, 2000). Given the unique composition of MCC, it is an attractive ingredient to produce purified nutraceutical derivatives from milk proteins or to be used in nutritional drinks that are high in protein and low in carbohydrate.

The MF permeate from MCC manufacturing can be processed to SPC, which is a nutritious and functional dairy protein. Compared with whey protein concentrate (WPC) derived from the cheesemaking whey, SPC is practically sterile, absent of cheesemaking residuals (milk coagulation enzymes, lactic acid, and starter culture), and has a minimal amount of fat (Britten and Pouliot, 1996). These composition differences affect sensory and functional properties. Serum protein concentrate has fewer lipid oxidation products and aroma-active compounds than WPC (Evans et al., 2010). In addition, SPC has better solubility, foaming, and gelling properties than WPC (Britten and Pouliot, 1996; Punidadas and Rizvi; 1998). Lactose recovered from MF milk permeate has higher purity and, consequently, higher lactose crystal recovery (Nelson and Barbano, 2005). This high-quality lactose might be preferred for certain niche markets, such as pharmaceutical and baby formulas.

\section{CONCLUSIONS}

A process to produce MCC18 with a long refrigerated microbial shelf life was developed. The MCC18 formed a solid gel at temperatures $<22^{\circ} \mathrm{C}$, but the MCC18 reverted back to a liquid when warmed from 4 to $>22^{\circ} \mathrm{C}$. This provides a unique opportunity in ingredient handling and packaging and eliminates the challenges encountered in reconstitution of dried milk protein ingredients. The MCC18 produced in this study maintained a bacterial count $<20,000 \mathrm{cfu} / \mathrm{mL}$ for $16 \mathrm{wk}$ when stored at a refrigeration temperature of $4^{\circ} \mathrm{C}$. Further study is needed to determine if changes occur in the organoleptic and functional properties of MCC18. We envision that the conversion of skim milk to MCC and its coproducts (SPC and lactose concentrate) could be used as an alternative to production of NDM to balance milk production seasonality, specifically the components of the skim milk portion.

\section{ACKNOWLEDGMENTS}

The authors thank the Northeast Dairy Foods Research Center (Ithaca, NY) and the New York State Milk Promotion Board for partial funding of this research. The technical assistance of Mark Newbold, Chassidy Coon, Michelle Bilotta, Maureen Chapman, Jessica Mallozzi, Sara Bova, Emily Hurt, and Michael Adams from the Department of Food Science at Cor- nell University (Ithaca, NY) and the staff of the Cornell Dairy Plant and Cornell Milk Quality Improvement Program was greatly appreciated.

\section{REFERENCES}

AOAC International. 2000. Official Methods of Analysis. 17th ed. AOAC International, Gaithersburg, MD.

Barbano, D. M., Y. Ma, and M. V. Santos. 2006. Influence of raw milk quality on fluid milk shelf life. J. Dairy Sci. 89:E15-E19.

Beckman, S. L., J. Zulewska, M. Newbold, and D. M. Barbano. 2010. Production efficiency of micellar casein concentrate using polymeric spiral-wound microfiltration membranes. J. Dairy Sci. 93:4506-4517.

Brans, G., C. G. P. H. Schroën, R. G. M. van der Sman, and R. M. Boom. 2004. Membrane fractionation of milk: State of the art and challenges. J. Membr. Sci. 243:263-272.

Britten, M., and Y. Pouliot. 1996. Characterization of whey protein isolate obtained from milk microfiltration permeate. Lait 76:255265.

Caplan, Z, C. Melilli, and D. M. Barbano. 2013. Gravity separation of fat, somatic cells, and bacteria in raw and pasteurized milks. J. Dairy Sci. http://dx.doi.org/10.3168/jds.2012-6006.

Dellagio, F., J. Stadhouders, and G. Hup. 1969. Distribution of bacteria between the bottom, middle, and cream layers of creamed raw milk. Neth. Milk Dairy J. 23:140-145.

Durham, R. J. 2009. Modern approaches to lactose production. Pages 103-144 in Dairy-Derived Ingredients: Food and Nutraceutical Uses. M. Corredig, ed. Woodhead Publishing Ltd., Cambridge, UK.

Evans, J., J. Zulewska, M. Newbold, M. A. Drake, and D. M. Barbano. 2009. Comparison of composition, sensory, and volatile components of thirty-four percent whey protein and milk serum protein concentrates. J. Dairy Sci. 92:4773-4791.

Evans, J., J. Zulewska, M. Newbold, M. A. Drake, and D. M. Barbano. 2010. Comparison of composition and sensory properties of $80 \%$ whey protein and milk serum protein concentrates. J. Dairy Sci. 93:1824-1843.

FDA (Food and Drug Administration). 2009. Grade "A" Pasteurized Milk Ordinance. Publication No. 229. US Dept. of Health and Human Services, Public Health Service, Washington, DC.

Fox, P. F., and P. L. H. McSweeney. 1998. Milk proteins. Pages 199200 in Dairy Chemistry and Biochemistry. Blackie Academic and Professional, London, UK.

Fromm, H. I., and K. J. Boor. 2004. Characterization of pasteurized fluid milk shelf-life attributes. J. Food Sci. 69:M207-M214.

Glantz, S. A., and B. K. Slinker. 2001. Multicollinearity and what to do about it. Pages 185-187 in Primer of Applied Regression and Analysis of Variance. 2nd ed. McGraw-Hill Inc., New York, NY.

Huffman, L. M., and W. J. Harper. 1999. Maximizing the value of milk through separation technologies. J. Dairy Sci. 82:2238-2244.

Hurt, E., and D. M. Barbano. 2010. Processing factors that influence casein and serum protein separation by microfiltration. J. Dairy Sci. 93:4928-4941.

Hurt, E., J. Zulewska, M. Newbold, and D. M. Barbano. 2010. Micellar casein concentrate production with a $3 \times, 3$-stage, uniform transmembrane pressure ceramic membrane process at $50^{\circ} \mathrm{C}$. J. Dairy Sci. 93:5588-5600.

Lynch, J. M., D. M. Barbano, and J. R. Fleming. 2007. Determination of the lactose content of fluid milk by spectrophotometric enzymatic analysis using weight additions and path length adjustment: Collaborative study. J. AOAC Int. 90:196-216.

Muir, D. D. 1996. The shelf-life of dairy products: IV. Intermediate and long life dairy products. Int. J. Dairy Technol. 49:119-124.

Mulvihill, D. M., and M. P. Ennis. 2003. Functional milk proteins: Production and utilization. Pages 1175-1219 in Advanced Dairy Chemistry: Volume 1: Proteins. P. F. Fox and P. L. H. McSweeney, ed. Kluwer Academic/Plenum Publishers, New York, NY.

Nelson, B. K., and D. M. Barbano. 2005. A microfiltration process to maximize removal of serum proteins from skim milk before cheese making. J. Dairy Sci. 88:1891-1900. 
Papadatos, A., M. Neocleous, A. M. Berger, and D. M. Barbano. 2003. Economic feasibility evaluation of microfiltration of milk prior to cheesemaking. J. Dairy Sci. 86:1564-1577.

Pierre, A., J. Fauquant, Y. Le Graet, M. Piot, and J. L. Maubois. 1992. Native micellar casein separation through cross flow membrane microfiltration. Lait 72:461-474.

Punidadas, P., and S. S. H. Rizvi. 1998. Separation of milk proteins into fractions rich in casein or whey proteins by cross flow filtration. Food Res. Int. 31:265-272.

Ray, B. 2003. Important factors in microbial food spoilage. Page 263 in Chapter 18 of Fundamentals of Food Microbiology. CRC Press, New York, NY.

Saboya, L. V., and J.-L. Maubois. 2000. Current developments of microfiltration technology in the dairy industry. Lait 80:541-553.
Wehr, M. H., and J. F. Frank, editors. 2004. Standard Methods for the Examination of Dairy Products. 17th ed. Am. Publ. Health Assoc. Inc., Washington, DC.

Weldon, R. N., A. A. Washington, and R. L. Kilmer. 2003. Reducing seasonality in dairy production. Choices (N.Y. N.Y.) 18:35-38.

Wolfschoon-Pombo, A., and H. Klostermeyer. 1981. The NPN fraction in cow milk. I. Amount and composition. Milchwissenschaft $36: 598-600$.

Zulewska, J., M. Newbold, and D. M. Barbano. 2009. Efficiency of serum protein removal from skim milk with ceramic and polymeric membranes at $50^{\circ} \mathrm{C}$. J. Dairy Sci. 92:1361-1377. 